\title{
ПРОДУКТИВНІ ЯКОСТІ ВІДГОДІВЕЛЬНОГО МОЛОДНЯКУ СВИНЕЙ ЗА РІЗНОГО РІВНЯ ПРОТЕЇНУ В РАЦІОНІ
}

Повод Микола Григорович

доктор сільськогосподарських наук, профресор Сумський національний аграрний університет ORCID ID: 0000-0001-9272-9672/ W-1565-2018 E-mail: nic.pov@ukr.net

Михалко Олександр Григорович аспірант спец. 204 ТВППТ Сумський національний аграрний університет ORCID ID: 0000-0002-0736-2296/ G-2305-2018 E-mail: snau.cz@ukr.net

Шпетний Микола Борисович кандидат сільськогосподарських наук, доцент Сумський національний аграрний університет ORCID: 0000-0003-4757-5875/ W-3978-2018

E-mail: nshpetny@gmail.com

Опара Віктор Олексійович кандидат сільськогосподарських наук, доцент Сумський національний аграрний університет ORCID ID: 0000-0002-8917-4423/V-6089-2018 E-mail: vopara@ukr.net

В статті порівняно інтенсивність росту, збереженість, конверсію корму та економічну ефективність відгодівлі свиней за додаткового введення 0,5\% загального протеїну в комбікорм «старт -15-30» для поросят другої фрази дорощування, «гравер-30-60» для підсвинків на першій стадії відгодівлі з живою масою від 31 до 60 ке, «фрінішер 60-90» та «фрінішер 90-130» для гібридних свиней від помісних свиноматок ірландської великої білої породи та кнурів ірландського

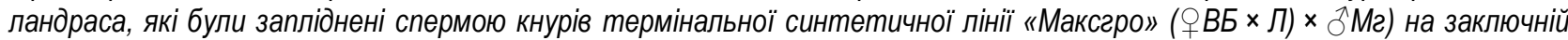
стадії мультисразної відгодівлі в кожний з періодів дорощування і відгодівлі. Встановлено, що додаткове введення 0,5\% загального протеїну в комбікорм сприяло в період відгодівлі кращій на 1,0\% збереженості поголів'я, вищми на 41 г середньодобовим приростам і, як результат, більшій на 2,7 кг масі тварин на день реалізації. За час відгодівлі вони витратили менше на 240 кг стартерного комбікорму, на 640 кг граверного і на 750 кг фрінішного корму рецепту 60-90. Водночас вони спожили на 890 кг більш дешевого фрінішеру 90-120. Загальна кількість спожитого корму виявилась меншою на 740 кг у тварин дослідної групи, але за рахунок різниці в ціні різних марок комбікорму його вартість була вищою для цієї групи на 9583,8 грн. В цілому конверсія корму у тварин дослідної групи виявилась кращою на 0,13 к2 в порівнянні з аналогами контрольної групи. За комплексом ознак відгодівельної продуктивності свині дослідної групи мали індекс відгодівельних якостей на 4,0 бали вищим в порівнянні з тваринами контрольної групи. За рахунок більш низької ціни фрінішного комбікорму 90-120 та вищої інтенсивності росту свиней в цей період, кормова собівартість 1 кг приросту свиней, які споживали додатково 0,5\% загального протеїну, виявилась на 0,49 грн. нижчою в порівнянні з тваринами контрольної групи. Також на 0,48 грн. була нижчою і собівартість 1 ке приросту у тварин дослідної групи.

Ключові слова: відгодівля, конверсія корму, інтенсивність росту, кормова собівартість, збереженість.

DOI: https://doi.org/10.32845/bsnau.Ivst.2021.3.10

Інтенсифікація тваринництва неможлива без повноцінної годівлі. Своєю чергою, годівля сільськогосподарських тварин повинна бути раціональною. За найменших витрат кормів необхідно одержувати потрібну кількість продукції високої якості, забезпечувати високу життє- і відтворну здатність. Забезпеченість свиней кормовим протеїном - одне з важливих завдань сільського господарства і тих промислових підприємств, які виробляють білкові корми або одержують їх у вигляді відходів своїх підприємств. Раціони для молодняку свиней, що складаються із зерносуміші, не забезпечують їх усіма конче потрібними елементами живлення [5].

Ключову роль у вирощуванні свиней відіграє раціональна і збалансована годівля, що передбачає не лише правильне складання раціонів і створення ефективної кормової бази, але й використання сучасних високоефективних систем годівлі. Збільшити виробництво продукції тваринництва, зокрема свинини, можна за рахунок застосування в годівлі тварин кормових добавок різної природи, що збагачують основний раціон [2].

Основною причиною зниженої продуктивності свиней $€$ дефіцит кормового білка, який в середньому становить 25$30 \%$. За нестачі білка в раціоні витрати кормів на виробництво одиниці продукції збільшуються в 1,4 рази [7].

Нестача протеїну в раціонах поросят як за кількістю, так і за якістю призводить до зниження синтезу білка, що значно впливає на ріст і розвиток поросят. Але надлишок протеїну в раціонах також небажаний, оскільки при цьому Вісник Сумського національного аграрного університету 
знижується ефрективність використання корму в організмі та збільшується витрата протеїну для одержання одиниці приросту [12].

Саме наявність незамінних амінокислот визначає біологічну цінність кормів. Відсутність або нестача незамінних амінокислот змінює азотний баланс на негативний, призводить до затримки росту та розвитку організму, до зменшення маси тіла, порушення обміну речовин. Якщо в раціоні не буде хоча б однієї незамінної амінокислоти в достатній кількості, то нормальний синтез білка буде заблоковано, а гостра недостатність незамінних амінокислот взагалі може призводити до загибелі організму [3].

Щоб краще забезпечувати потреби свиней у поживних речовинах, доцільно годувати тварин фразово. Такий підхід дозволяє якнайкраще збалансувати потребу в білку і його пропозицію, а також забезпечити свиней амінокислотами та мінералами у найоптимальніший та най економніший спосіб [11].

Енергія росту свиней проявляється повністю лише тоді, коли тварини систематично одержують достатню кількість біологічно повноцінного протеїну, комплекс вітамінів і мінеральних речовин. Кожен протеїн складається з окремих азотистих компонентів - амінокислот [8].

Ступінь засвоєння тваринами протеїну, що міститься в кормі, залежить від співвідношення в ньому незамінних амінокислот: лізину, метіоніну, треоніну, триптофрану. Оскільки ці амінокислоти не синтезуються в організмі свиней, дефіцит в раціоні будь-якої з них порушує обмінні процеси і знижує продуктивність тварин [9].

Балансування раціонів за амінокислотами, сприяє суттєвому поліпшенню використання азоту (на 60\%) і тим самим підвищенню біологічної цінності протеїну корму. Застосування в якості кормових добавок синтетичних препаратів амінокислот дозволяє скоротити витрати сої в 5-7 разів, протеїну - на 34\%, підвищити ефективність використання азоту на 54 ... 60\%, корми - на $23 . . .32 \%$ без шкоди для продуктивності тварин [6].

Встановлено, що зниження рівня білка в раціоні молодняку свиней сприяло різкому зниженню добових приростів (на 26\%). Додавання в низькобілковий раціон відсутніх амінокислот - лізину, метіоніну і треоніну до фізіологічних норм потреби, сприяло підвищенню добових приростів на 54\% (з 217г до 334) [10].

Корекція раціону за доступними амінокислотам в виробничих дослідженнях при рівні сирого протеїну в ньому на 10-25\% нижче діючих норм дозволила збільшити продуктивність свиней більш, ніж на 20\%, зменшити витрату кормів більше, ніж на 14,5\%, а також в два рази збільшити умовний прибуток [4].

Зменшення вмісту харчового білка на 3,5 \% не чинить несприятливого впливу на продуктивність росту та засвоюваність поживних речовин поросят [17].

Утримання поросят на раціоні зі зниженим рівнем білка покращувало ріст і обмін речовин за рахунок поліпшення мікрофрлори кишечника [15].

Незважаючи на високу засвоюваність, раціон з високим вмістом білка викликав діарею у поросят в знижував показники їх росту після відлучення [14].

Підвищений рівень білка в раціоні має негативний вплив на здоров'я та добробут свиней, оскільки спричиняє проблеми з травленням у поросят при відлученні через шкідливу дію на їх метаболізм [13].

На противагу в інших дослідженнях поросята, яких годували низьким або стандартним білковим раціоном, мали різноманітні порушення метаболізму. Годування поросят 3 помірно низьким вмістом білка привело до зменшення споживання корму, маси тіла та конверсії корму, але збільшило витрати енергії, тоді як годування їх раціоном із дещо низьким вмістом білка не вплинуло на продуктивність росту [16].

Таким чином, питання збагачення раціону свиней протеїновими добавками піднімалося багатьма дослідниками, але однозначного позитивного, чи негативного результату не було знайдено.

Отже, процес введення додаткового протеїну в раціон свиней має як свої переваги, так і недоліки та відповідно потребує додаткового вивчення.

Метою роботи було вивчення впливу додаткового введення 0,5\% загального протеїну в комбікорм «старт -1530» для поросят другої фази дорощування, «гравер - 30-60» для підсвинків на першій стадії відгодівлі з живою масою від 31 до 60 кг, «фінішер 60-90» та «фінішер 90-130» для свиней на заключній стадії мультисразної відгодівлі на інтенсивність росту свиней, щодобові витрати корму та його конверсію, збереженість тварин в кожний з періодів дорощування і відгодівлі та економічну ефективність його використання.

Матеріали та методи досліджень. Матеріалом для дослідження слугували гібридні свині від помісних свиноматок ірландської великої білої породи та кнурів ірландського ландраса які були осіменені спермою кнурів термінальної синтетичної лінії «Максгро» (ОВБ $\times$ Л) × О̄ Мг). Експерименти проведено в умовах промислового свинокомплексу ТОВ «НВП «Глобинський свинокомплекс» на поросятах та свинях технологічної групи 4419 в цеху з відгодівлі свиней №1 3 використанням сортувальної станції «трисорт» відповідно до схеми наведеній в табл. 1

Таблиця 1

Схема досліду по згодовуванню додатково $0,5 \%$ загального протеїну в комбікорм свиням на дорощуванні і відгодівлі (n=300 гол)

\begin{tabular}{|l|c|c|}
\hline & Контрольна група & Дослідна група \\
\hline Цех дорощування № & Згодовування комбікорму Старт 15-30 відповідно до рецептури свинокомплексу \\
\hline Цех відгодівлі №1 МПВЯ & Згодовування комбікорму Гровер 30-60, Фінішер & Згодовування комбікорму Гровер 30-60, Фінішер 60-90 \\
& $\begin{array}{c}\text { 60-90 та 90-130 відповідно до рецептури прийнятої } \\
\text { на час досліду в господарстві }\end{array}$ & $\begin{array}{c}\text { та 90-130 з додаванням 0,5\% загального протеїну до } \\
\text { рецептури прийнятої на час досліду в господарстві }\end{array}$ \\
\hline
\end{tabular}

Для проведення досліджень починаючи з в квітня 2020 року при постановці в приміщення цеху відгодівлі №1 обладнане сортувальною станцією «трисорт» (рис. 1), на якій проводилось автоматичне зважування тварин за мето- дом груп аналогів, було сформовано дві групи піддослідних підсвинків середньою масою 15 кг в кількості 300 голів кожна.

Вісник Сумського національного аграрного університету 


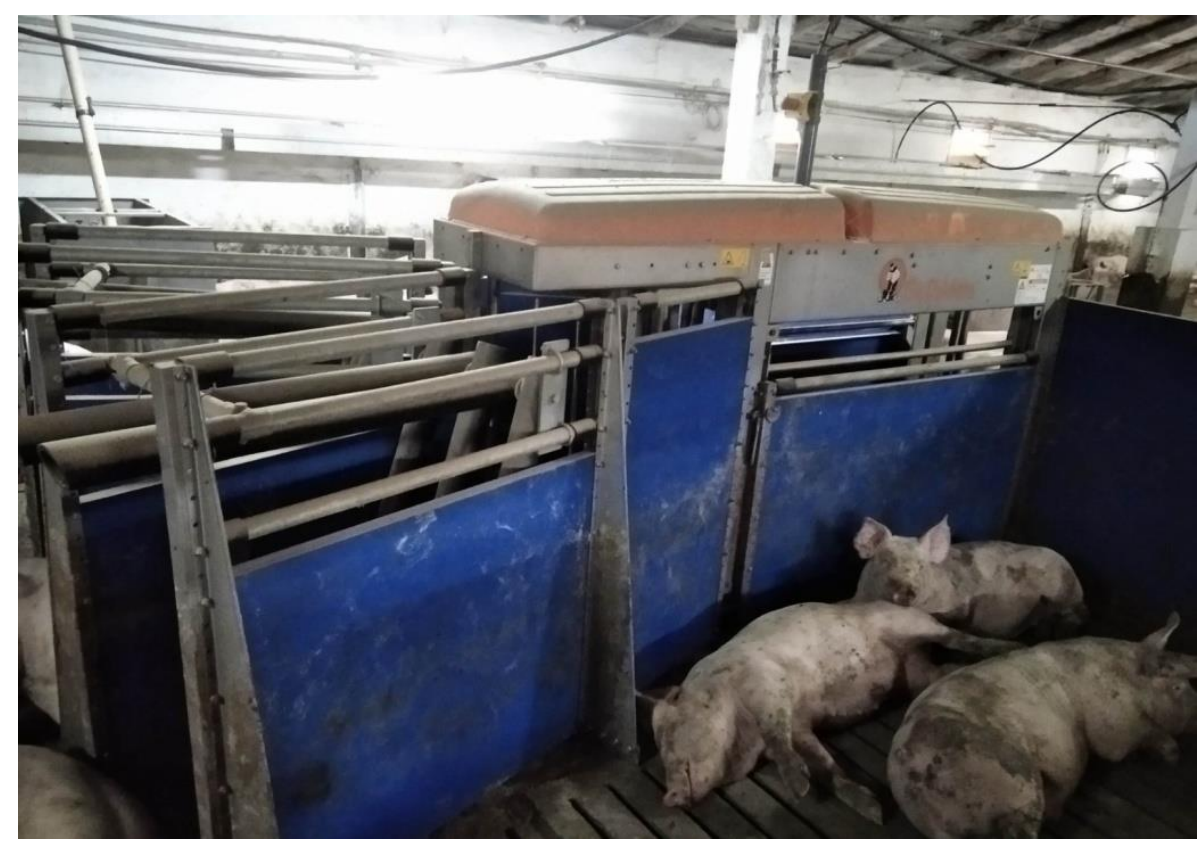

Рис.1. Сортувальна станція трисорт

Годівля тварин впродовж всього досліду здійснювалась сухими повнораціонними комбікормами зі зволоженням їх в кормових автоматах американської фрірми Hog Slat. Транспортування корму із бункерів-накопичувачів до кормових автоматів здійснювалось за допомогою ланцюговошайбового транспортера та системи опусків. Його зважування для кожної групи проводилось за допомогою торзіонних вагів. Корм до бункера кормового автомату потрапляв у сухому вигляді і зволожувався за допомогою зрошувачів розташованих в жолобі кормового автомату. Фронт годівлі був 0,1 м на одну голову. Умови утримання, напування i вентилювання приміщення були ідентичними. Тварин утримували по 50 голів в станку на повністю щілинній підлозі, 3 розрахунку 0,7 м² на одну голову. Гноєвидалення 3 приміщення відбувалось за допомогою вакуумно-самопливної системи періодичної дії. Напування свиней відбувалось за допомогою регульованих ніпельних автонапувалок з розрахунку 10 голів на напувалку. Підтримання мікроклімату за допомогою вентиляції негативного тиску та зрошувачів повітря фірми Біг Дачмен.

Контрольна група свиней отримувала впродовж всього періоду відгодівлі комбікорми «старт -15-30», «гравер - 30-60», «фрінішер 60-90» та «фінішер 90-130» відповідно до рецептури прийнятої в господарстві.

Дослідна група тварин отримувала аналогічний комбікорм з додаванням 0,5\% загального протеїну за рахунок підняття нелімітуючих амінокислот. При цьому рівень введення лімітуючих амінокислот був однаковим для обох груп тварин і контролювався незалежною лабораторією. Загальний білок контролювався лабораторією комбікормового заводу свинокомплексу при виготовлені кожної партії комбікорму.
Щоденно за допомогою сортувальної станції «трисорт» враховувався в обох групах тварин кількість з'їденого корму, маса тварин та заносились в відповідну відомість досліду. При вибутті свиней з групи ффіксувались дата та причина вибуття і маса тварин що вибули. По переведені на наступний рецепт комбікорму розрахувались - збереженість свиней. Також на основі даних сортувальної станції «трисорт» враховувалась щоденна динаміка споживання корму і його конверсія та середньодобові прирости. По закінчені відгодівлі на основі даних облікової відомості ці ж показники вирахувані за весь період досліду і на їх основі розрахована економічна ефективність додаткового введення 0,5\% загального протеїну в комбікорми для дорощуванні і відгодівлі.

Для оцінки відгодівельних характеристик дослідних свиней було використано комплексний індекс відгодівельних якостей за формулою М.Д. Березовського [1]:

$$
I=\frac{\mathrm{A}^{2}}{\mathrm{~B} * C}
$$

де: А - валовий приріст за період відгодівлі, кг;

В - кількість діб відгодівлі;

C - витрати корму на 1 кг приросту.

Результати досліду були обраховані біометрично за допомогою прикладних програм Microsoft Office Excel.

Результати досліджень. досліду встановлено, що свині яким додатково згодовували 0,5\% загального протеїну за період відгодівлі мали кращу на 1,0\% збереженість поголів'я, вищі на 41 г середньодобові прирости і як результат більшу на 2,7 кг масу на день реалізації (табл. 2). 
Таблиця 2

Кількість, маса, валовий приріст та збереженість піддослідних свиней

\begin{tabular}{|l|c|c|}
\hline \multicolumn{1}{|c|}{ Показник } & \multicolumn{2}{c|}{ Група свиней } \\
\cline { 2 - 3 } & Контрольна & Дослідна \\
\hline Кількість голів, гол & 391 & 391 \\
\hline Маса при постановці, кг & 8132,5 & 2132,5 \\
\hline Середня маса 1 голови, кг & $20,80 \pm 1,36$ & $426,80 \pm 1,39$ \\
\hline Кормодні & 42461 & 36587,18 \\
\hline Валовий приріст, кг & 35003,64 & 44719,68 \\
\hline Маса реалізованих свиней, кг & 43136,14 & 385 \\
\hline Кількість свиней на дату закінчення досліду, голів & 381 & 111 \\
\hline Тривалість відгодівлі, діб & 113 & $116,2 \pm 5,7$ \\
\hline Середня маса реалізованих свиней, кг & $113,5 \pm 2,9$ & 98,4 \\
\hline Збереженість свиней, \% & 97,4 & 32,9 \\
\hline Індекс відгодівельних якостей & 28,9 & \\
\hline
\end{tabular}

За час відгодівлі вони витратили менше на 240 кг стартерного комбікорму, на 640 кг граверного і на 750 кг фінішного корму рецепту 60-90. Водночас вони спожили на 890 кг більш дешевого фінішеру 90-120. Загальна кількість спожитого корму виявилась меншою на 740 кг у тварин дослідної групи, але за рахунок різниці в ціні різних марок комбікорму його вартість була вищою для цієї групи на 9583,8 грн. (табл. 3). В цілому конверсія корму у тварин дослідної групи виявилась кращою на 0,13 кг в порівнянні 3 аналогами контрольної групи.

Таблиця 3

Витрати комбікорму різних рецептур, його вартість та конверсія

\begin{tabular}{|l|c|c|}
\hline \multirow{2}{*}{\multicolumn{2}{|c|}{ Показник }} & \multicolumn{2}{|c|}{ Група } \\
\cline { 2 - 3 } & кослідна \\
\cline { 2 - 3 } & кількість спожитого комбікорму, кг & кількість спожитого комбікорму, кг \\
\hline Старт & 7300,5 & 7060 \\
\hline Гровер & 26320 & 25680 \\
\hline Фінішер 1 & 28690 & 27940 \\
\hline Фінішер 2 & 29860 & 30750 \\
\hline Всього & 92170,5 & 91430 \\
\hline Вартість комбікорму на групу, грн. & 603673,06 & 613256,9 \\
\hline Конверсія корму, кг & 2,63 & 2,50 \\
\hline
\end{tabular}

Свині яким згодовували додатково 0,5\% загального протеїну в перші періоди відгодівлі за згодовування їм стартерного та гроверного комбікорму мали суттєво нижчі середньодобові прирости живої маси, які за час годівлі фінішним комбікормом рецепту 60-90 дещо вирівнялись. Тоді як на заключній стадії відгодівлі свині яким додатково до раціону вводили $0,5 \%$ загального протеїну мали на 320 г або на 43,2\% вищі середньодобові прирости (табл. 4), що й призвело до переваги на 2,7 кг в середній масі тварин підчас відвантаження їх на м'ясокомбінат. Середньодобові прирости за весь період відгодівлі також були вірогідно на 41 г вищими $(p<0,05)$ у свиней яким додатково згодовували $0,5 \%$ загального протеїну. За комплексом ознак відгодівельної продуктивності свині дослідної групи мали індекс відгодівельних якостей на 4,0 бали вищим в порівнянні з тваринами контрольної групи.

Інтенсивність росту свиней за різних рецептів комбікорму

Таблиця 4

\begin{tabular}{|c|c|c|c|c|}
\hline \multirow[b]{3}{*}{ Показник } & \multicolumn{4}{|c|}{ Група свиней } \\
\hline & \multicolumn{2}{|c|}{ Контрольна } & \multicolumn{2}{|c|}{ Дослідна } \\
\hline & $\begin{array}{c}\text { Середня маса } \\
\text { на дату } \\
\text { переводу, кг }\end{array}$ & $\begin{array}{c}\text { Середньо-добовий } \\
\text { приріст, г }\end{array}$ & $\begin{array}{c}\text { Середня } \\
\text { маса на дату } \\
\text { переводу, кг }\end{array}$ & $\begin{array}{c}\text { Середньо-добовий } \\
\text { приріст, г }\end{array}$ \\
\hline Старт & $32,23 \pm$ & 700 & $31,15 \pm$ & 540 \\
\hline Гровер & 64,23 & 1060 & 59,31 & 980 \\
\hline Фініш 1 & 95,69 & 950 & 90,16 & 930 \\
\hline Фініш 2 & $114,90 \pm 1,3$ & 740 & $117,82 \pm 1,6$ & 1060 \\
\hline Середньодобовий приріст за весь період відгодівлі, г & \multicolumn{2}{|c|}{$820 \pm 11,6$} & \multicolumn{2}{|c|}{$861 \pm 15,2^{*}$} \\
\hline Середня маса реалізованих свиней, кг & \multicolumn{2}{|c|}{$113,5 \pm 1,3$} & \multicolumn{2}{|c|}{$116,2 \pm 1,7$} \\
\hline
\end{tabular}

За рахунок більш низької ціни фінішного комбікорму 90-120 та вищої інтенсивності росту свиней в цей період кормова собівартість 1 кг приросту свиней які споживали додатково 0,5\% загального протеїну виявилась на 0,49 грн. нижчою в порівнянні з тваринами контрольної групи. Також на 0,48 грн. була нижчою і собівартість 1 кг приросту у тварин дослідної групи. I як результат економічний ефект від згодовування додатково 0,5\% загального протеїну складає на все поголів'я свинокомплексу в місяць 832224 грн. а в розрахунку на рік він складе 10818 915грн.

Висновок. Згодовування додатково до раціону 0,5\% загального протеїну сприяло кращій на 1,0\% збереженості поголів'я свиней, вірогідно вищим на 40 г середньодобовим приростам, більшій на 2,7 кг масі свиней на день реалізації, кращій на 0,13 кг конверсії і як наслідок нижчій на 0,49 грн. кормовій собівартості 1 кг приросту та на 0,48 грн. загальної собівартості 1 кг приросту. 


\section{Список використаної літератури:}

1. Березовский Н. Д. Селекционная работа с крупной белой породой свиней в Украине. Современные проблемы интенсификации производства свинины: мат. межд. конф. Ульяновск. 2007. Т.1. С. $29-33$.

2. Білявцева В. В. Продуктивність молодняку свиней за згодовування білково-вітамінно-мінеральної добавки «ЕНЕPBIК». Дисертація на здобуття на здобуття наукового ступеня доктора філософії (кандидата сільськогосподарських наук). Вінниця, 2017.

3. Бондаренко В.В. Використання білково-вітамінної мінеральної добавки «мінактивіт» в годівлі молодняку свиней. Дисертація на здобуття на здобуття наукового ступеня доктора філософії (кандидата сільськогосподарських наук). Біла Церква. 2017.

4. Головко Е. Н., Забашта Н. Н. Истинная доступность аминокислот кормов в органическом животноводстве. Сборник научных трудов СКНИИЖ. 2017. №2. URL: https://cyberleninka.ru/article/n/istinnaya-dostupnost-aminokislot-kormov-Vorganicheskom-zhivotnovodstve (дата звернення: 10.08.2021).

5. Карунський О., Кишлали О. Шляхи збалансування раціонів свиней за протеїном. Пропозиція - Головний журнал з питань агробізнесу. 2008. URL: https://propozitsiya.com/ua/shlyahi-zbalansuvannya-racioniv-sviney-za-proteyinom

6. Кулинцев В. В. Влияние сбалансированности рационов по незаменимым аминокислотам на продуктивность молодняка свиней. Достижения науки и техники АПК, НТП: Животноводство и кормопроизводство, 2011, Выпуск 2, с. 39-41. URL:https://cyberleninka.ru/article/n/vliyanie-sbalansirovannosti-ratsionov-po-nezamenimym-aminokislotam-na-produktivnostmolodnyaka-sviney/viewer

7. Лавринюк О. О., Бурлака В. А. Бобові корми в раціонах свиней: монографія. Житомир. 2016. 162 с.

8. Любасюк Н. В. Використання білково-вітамінно-мінеральної добавки інтермікс у годівлі свиней. Дисертація на здобуття наукового ступеня кандидата сільськогосподарських наук. Біла Церква. 2018. URL: https://science.btsau.edu.ua/sites/default/files/specradi/diser_lubasuk.pdf

9. Омаров М. О., Головко Е. Н., Слесарева О. А. Механизм балансирования рационов для свиней по протеину. Сборник научных трудов СКНИИЖ. 2012. №1. URL: https://cyberleninka.ru/article/n/mehanizm-balansirovaniya-ratsionov-dlya-svineypo-proteinu (дата звеонення: 10.08.2021).

10. Омаров М. О., Слесарева О. А., Османова С.О. Эфффективность низкобелковых рационов в кормлении молодняка свиней // Сборник научных трудов СКНИИЖ. 2017. №1. URL: https://cyberleninka.ru/article/n/effektivnost-nizkobelkovyhratsionov-v-kormlenii-molodnyaka-sviney (дата звернення: 10.08.2021).

11. Соняшниковий чи соєвий шріт для свиней на відгодівлі? 2015. URL: http://pigua.info/uk/post/sonasnikovii-ci-soeviisrit-dla-svinej-na-vidgodivli-uk (дата звернення: 10.08.2021).

12. Як годувати підсисних поросят? Правильне і ефективне годування поросят-сисунів. Перший в Україні комплексний сервіс з годівлі продуктивних тварин. 2014. URL: https://www.ankores.com.ua/ua/publications/yak-goduvati-podsosnikhporosyat-pravilne-i-efektivne-goduvannya-porosyat-sisuniv/ (дата звернення: 10.08.2021).

13. Aguilera J. F., Lara L., Aguinaga M. A., Barea R., Aguilera J. A. C., García-Valverde R.,. An overview of protein nutrition of the pure Iberian pig. 4. International Congress New Perspectives and Challenges of Sustainable Livestock Production, Belgrado, Serbia. 2015. URL: https://hal.archives-ouvertes.fr/hal-01455883/document (дата звернення: 10.08.2021).

14. Gao J., Yin J., Xu K., Han H., Liu Z.M., Wang C.Y., Li T.J and Yin Y.L. The Impact of Nutrients, Dietary Components and Derivatives on the Gut Microbiota and Inflammation-Related Diseases, from Molecular Basis to Therapy. Mediators of Infla?mation. Special Issue 2020. DOl.org/10.1155/2020/1937387 (дата звернення: 10.08.2021).

15. Liu R., He J., Ji X., Zheng W., Yao W. Moderate Reduction of Dietary Crude Protein Provide Comparable Growth Performance and Improve Metabolism via Changing Intestinal Microbiota i Sushan Nursery Pigs. Animals, 2021, №11, pp. 1166. DOl.org/10.3390/ani11041166

16. Spring S., Premathilake H., DeSilva U. et al. Low Protein-High Carbohydrate Diets Alter Energy Balance, Gut Microbiota Composition and Blood Metabolomics Profile in Young Pigs. Sci Rep. 2020. 10. 3318 https://doi.org/10.1038/s41598-020-60150-y

17. Zhao Y., Tian G., Chen D., Zheng P., Yu J., He J., Mao X., Yu B. Effects of varying levels of dietary protein and net energy on growth performance, nitrogen balance and faecal characteristics of growing-finishing pigs. Brazilian Journal of Animal Science. 2019. 48:e20180021, https://doi.org/10.1590/rNbozn4-8r2u0m1i8n0a0n2t1 (дата звернення: 10.08.2021).

\section{References:}

1. Berezovsky N.D., 2007. Electio operis cum magno albo porcorum in Ucraina [Selection work with a large white breed of pigs in Ukraine]. Problemata hodierna intensio productionis suillae: mat. int. conf. Ulyanovsk, Vol.1, pp. 29-33.

2. Bilyavtseva V.V., 2017. Productio porcorum pullorum ad supplementum vitaminum-minel alendis dapibus "enervic". Dissertatio medica de gradu Doctoris Philosophiae (Candidate of Sciences Agricultural). Vinnitsa.

3. Bondarenko V.V., 2017. Usus interdum-vitaminorum supplementum minerale "minactivit" in pastu porcorum pullorum. Dissertatio medica de gradu Doctoris Philosophiae (Candidate of Sciences Agricultural). Bila Tserkva.

4. Golovko E.N., Zabashta N.N., 2017.Vera dispositio amino acida pascendi in organicis agriculturae animalis [True availability of feed amino acids in organic animal husbandry]. Collectio operum scientificorum SKNIIZh. №2. Available at: <https://cyberleninka.ru/article/n/istinnaya-dostupnost-aminokislot-kormov-v organicheskom-zhivotnovodstve> [accessum date: 10.08.2021].

5. Karunsky O., Kishlaly O., 2008. Mores ad paria dietas porcorum pro interdum [Ways to balance the diets of pigs for protein]. Rogatio - Summa emporium de agribusiness. Available at: <https://propozitsiya.com/ua/shlyahi-zbalansuvannya-racionivsviney-za-proteyinom> 
6. Кулинцев В., 2011. Effectus temperatae diets de amino acida essentiali in fructibus porcorum pullorum [The effect of balanced diets on essential amino acids on the productivity of young pigs]. Res gestae scientiarum et technologiarum complexus agro-industriae, NTP: pecuaria et pabularum productio, part 2, pp. 39-41. Available at: <https://cyberleninka.ru/article/n/vliyaniesbalansirovannosti-ratsionov-po-nezamenimym-aminokislotam-na-produktivnost-molodnyaka-sviney/viewer>

7. Lavrinyuk O.O., Burlaka V.A., 2016. Bean in victu porcorum pascuntur [Bean feed in the diets of pigs]. A monographo. Zhytomyr, pp. 162.

8. Lyubasyuk N.V., 2018. Usus supplementi interdum-vitamini-minel intermixti in pastione sus [The use of protein-vitaminmineral supplement intermix in pig feeding]. Dissertatio medica de gradu scientiarum candidatorum scientiarum agriculturae. Bila Tserkva. Available at: < https://science.btsau.edu.ua/sites/default/files/specradi/diser_lubasuk.pdf>

9. Omarov M.O., Golovko E.N., Slesareva O.A., 2012. Mechanismus conpensationis salariorum porcorum in interdum [The mechanism of balancing rations for pigs on protein]. Collectio operum scientificorum SKNIIZH. №1. Available at: $<$ https://cyberleninka.ru/article/n/mehanizm-balansirovaniya-ratsionov-dlya-sviney-po-proteinu> [accessum date: 10.08.2021].

10. Omarov M.O., Slesareva O.A., Osmanova S.O., 2017. Efficientia humili- interdum cibaria in pastu porcorum pullorum [Efficiency of low-protein rations in feeding of young pigs]. Collectio operum scientificorum SKNIIZh. №1. Available at: <https://cyberleninka.ru/article/n/effektivnost-nizkobelkovyh-ratsionov-v-kormlenii-molodnyaka-sviney> [accessum date: 10.08.2021].

11. Sunflower or soybean meal for fattening pigs? 2015. Available at: <Pig.uahttp://pigua.info/uk/post/sonasnikovij-ci-soevijsrit-dla-svinej-na-vidgodivli-uk>

12. How to feed suckling piglets? Proper and effective feeding of suckling piglets, 2014. The first in Ukraine comprehensive service for feeding productive animals. Available at: https://www.ankores.com.ua/ua/publications/yak-goduvati-podsosnikh-porosyatpravilne-i-efektivne-goduvannya-porosyat-sisuniv/

13. Aguilera J. F., Lara L., Aguinaga M. A., Barea R., Aguilera J. A. C., Garcia-Valverde R., 2015. An overview of protein nutrition of the pure Iberian pig. 4. International Congress New Perspectives and Challenges of Sustainable Livestock Production, Belgrado, Serbia. Available at: <https://hal.archives-ouvertes.fr/hal-01455883/document>

14. Gao, J., Yin, J., Xu, K., Han, H., Liu, Z.M., Wang, C.Y., Li, T.J and Yin Y.L., 2020. The Impact of Nutrients, Dietary Components and Derivatives on the Gut Microbiota and Inflammation-Related Diseases, from Molecular Basis to Therapy. Mediators of Inflammation. Special Issue 2020. doi.org/10.1155/2020/1937387.

15. Liu R., He J., Ji X., Zheng W., Yao W., 2021. A Moderate Reduction of Dietary Crude Protein Provide Comparable Growth Performance and Improve Metabolism via Changing Intestinal Microbiota i Sushan Nursery Pigs. Animals, №11, pp. 1166. doi.org/10.3390/ani11041166.

16. Spring S., Premathilake H., DeSilva U. et al., 2020. Low Protein-High Carbohydrate Diets Alter Energy Balance, Gut Microbiota Composition and Blood Metabolomics Profile in Young Pigs. Sci Rep 10, 3318 doi.org/10.1038/s41598-020-60150-y.

17. Zhao Y., Tian G., Chen D., Zheng P., Yu J., He J., Mao X., Yu B., 2019. Effects of varying levels of dietary protein and net energy on growth performance, nitrogen balance and faecal characteristics of growing-finishing pigs. Brazilian Journal of Animal Science. 48:e20180021. doi.org/10.1590/rNbozn4-8r2u0m1i8n0a0n2t1.

Povod Mykola Hryhorovych, Doctor of Agricultural Sciences, Professor

Mykhalko Oleksandr Hryhorovych, graduate student, specialty 204 TPPLP

Shpetnyi Mykola Borysovych, PhD of Agricultural Sciences, Docent

Opara Viktor Oleksiiovych, PhD of Agricultural Sciences, Docent

Sumy National Agrarian University (Sumy, Ukraine)

Productive qualities of a fattening young pigs at different levels of protein in the diet

The article compared the growth rate, safety, feed conversion and economic efficiency of pigs fattening with an additional introduction $0.5 \%$ of total protein into the "start-15-30" compound feed for piglets in the second stage of rearing, "engraver-30-60" for piglets in the first stages of fattening with live weight from 31 to $60 \mathrm{~kg}$, "finisher 60-90" and "finisher 90-130" for hybrid pigs from crossbred sows of the Irish Large White breed and boars of the Irish Landrace, which were fertilized with the semen of boars of the terminal synthetic line "Maxgro" ( $(+\vee B \times L) \times M g)$ at the final stage of multiphase feeding in each of the rearing and fattening periods. It was found that the additional introduction of $0.5 \%$ of the total protein in the feed during the feeding period contributed to the better by $1.0 \%$ safety of the livestock, higher by $41 \mathrm{~g}$ average daily gains and, as a result, more by $2.7 \mathrm{~kg}$ of weight on the day of sale. During the fattening period, they spent less on $240 \mathrm{~kg}$ of starter compound feed, $640 \mathrm{~kg}$ of engraving feed and $750 \mathrm{~kg}$ of finishing recipe feed 60-90. At the same time, they consumed $890 \mathrm{~kg}$ more than the cheap finisher 90-120. The total amount of feed consumed turned out to be $740 \mathrm{~kg}$ less in the animals of the experimental group, but due to the difference in the price of various brands of compound feed, its cost was higher for this group by UAH 9583.8. In general, the conversion of feed in the animals of the experimental group was $0.13 \mathrm{~kg}$ better than the analogs of the control group. According to the complex of signs of fattening performance, the pigs of the research group had the index of fattening qualities by 4.0 points higher than in the animals of the control group. Due to the lower price of the finishing compound feed 90-120 and the higher growth rate of pigs during this period, the feed cost of $1 \mathrm{~kg}$ of the increase in pigs, which consumed an additional $0.5 \%$ of the total protein, turned out to be UAH 0.49. Iower in comparison with animals of the control group. Also by UAH 0.48 was lower and the cost of $1 \mathrm{~kg}$ of gain in animals of the experimental group.

Key words: fattening, feed conversion, growth rate, feed cost, preservation.

Дата надходження до редакції: 02.09.2021 р. 